\title{
The Effect of Monetary Policy on Commodity Prices: Disentangling the Evidence for Individual Prices
}

\author{
Carolina Arteaga Cabrales, ${ }^{1}$ Joan Camilo Granados Castro, ${ }^{1}$ and Jair Ojeda Joya ${ }^{2}$ \\ ${ }^{1}$ Inflation and Macroeconomic Programming Department, Banco de la República, Colombia \\ ${ }^{2}$ Research Unit, Banco de la República, Carrera 7 No. 14-78, Bogotá, Colombia \\ Correspondence should be addressed to Joan Camilo Granados Castro; jgranaca@banrep.gov.co
}

Received 2 April 2014; Revised 4 August 2014; Accepted 14 August 2014; Published 24 December 2014

Academic Editor: Jean Paul Chavas

Copyright (c) 2014 Carolina Arteaga Cabrales et al. This is an open access article distributed under the Creative Commons Attribution License, which permits unrestricted use, distribution, and reproduction in any medium, provided the original work is properly cited.

\begin{abstract}
We study the effect of monetary policy shocks on commodity prices. While most of the literature has found that expansionary shocks have a positive effect on aggregate price indices, we study the effect on individual prices of a sample of four commodities. This set of commodity prices is essential to understand the dynamics of the balance of payments in Colombia. The analysis is based on structural VAR models; we identify monetary policy shocks following Kim $(1999,2003)$ upon quarterly data for commodity prices and their fundamentals for the period from 1980q1 to 2010q3. Our results show that commodity prices overshoot their long run equilibrium in response to a contractionary shock in the US monetary policy and, in contrast with literature, the response of the individual prices considered is stronger than what has been found in aggregate indices. Additionally, it is found that the monetary policy explains a substantial share of the fluctuations in prices.
\end{abstract}

\section{Introduction}

The evolution of commodity prices has been one of the major sources of concern for policy makers during the past decades. From emerging countries to developed markets around the world, commodity prices have a great influence on the dynamics of economic activity, their international trade represents one-quarter of the world's merchandise exchange [1], and a large share of developing world's GDP comes from commodity related activities. Hence, both long-term trends and short-term fluctuations in commodity prices are key determinants of exchange rates, prices, national income, and the balance of payments.

Commodity markets are characterized by spreading shocks between markets; they connect commodity-importing countries, usually developed economies, with emerging exporter countries; see Borensztein and Reinhart [2]. On the supply side, many developing countries are highly dependent on commodity exports income, and on the demand side, commodity markets play an important role as they transmit shocks from the world economic cycle to inflation in most economies. Additionally, in countries with low monetary policy credibility and where the share of commodities in the consumption basket is large, food and fuel price shocks might also raise expectations of larger inflation in the future and might thereby raise pass-through to headline inflation.

Unlike manufactured goods, primary products have flexible prices which respond very quickly to macroeconomic fundamentals and other international finance concepts [3]. Therefore, some macroeconomic concepts can be used in their analysis, for example, the neutrality of money, the interest rate parity, rational expectations, and particularly Dornbusch [4] overshooting model (given the fact that commodity prices behave similarly to financial assets, they may be good predictors of future changes in aggregate price levels and production. Therefore, they can be used as a leading indicator for economic activity. For further discussion on the features of commodity prices see Frankel [5] and Flórez [6]).

During the recent surge on commodity prices, some authors argue that the loose monetary policy and persistently low interest rates could have partly fuelled the price increase $($ see $[7,8])$. If that is the case it becomes relevant to understand to what extent the recent US monetary policy easing affects developments on commodity prices. For countries like 
Colombia, commodity exports represent a significant share of total exports. In 2010, for example, oil, coal, ferronickel, and gold exports accounted for $64 \%$ of total exports.

In this paper, we study the effect of monetary policy shocks on commodity prices focusing on individual products mentioned in the previous paragraph that are essential for understanding the dynamics of the balance of payments in Colombia. The analysis is based on structural VAR models following Kim [9] and Kim [10] monetary policy shocks identification strategy. The model is estimated with quarterly data for these prices and their fundamentals for the period from 1980q1 to 2010q3. Our results suggest that there is an overshooting behaviour of the commodity prices. Nevertheless, in contrast with the literature, the response of the individual prices considered is stronger than what has been found in aggregate indices.

This document consists of five sections including this introduction. Section 2 provides a brief literature review that shows different empirical approaches to the relationship between commodity prices and its fundamentals with an emphasis on monetary policy. Section 3 presents the theoretical model and the econometric strategy. Section 4 describes the results and, finally, Section 5 concludes.

\section{Literature Review}

2.1. A Summary of the Theoretical Approaches. The first approaches of literature that tried to explain the behavior of commodity prices relied exclusively on demand factors. In this line of research, it was found that the economic cycle and the real exchange rate of the United States accounted for most of the movements in the international prices of primary goods. The evolution of economic activity drives the demand for commodity products and it is, therefore, a critical determinant of its price. Similarly, the exchange rate is a variable that influences the price of commodities since it affects the competitiveness of producers and the purchasing power of consumers. Thus exchange rate fluctuations affect both the supply and the demand side of such basic goods.

However, when only demand-side determinants were used, prices forecasts showed positive biases in their estimations and current fundamentals could not explain the low prices observed in the nineties. A closer look at the information showed that while commodity prices fell down, imports from developed countries grew strongly, and it was found that in the mid-eighties the global supply of basic goods grew at an annual rate of $13 \%$. This growth was driven by technological innovation and by higher trade openness in developing countries. Economists, therefore, realized the importance of analyzing supply-side variables. Borensztein and Reinhart [2] survey related literature on these approaches.

While supply and demand can in general explain a large share of commodity prices fluctuations, other forces might play an important role $[7,8]$. In his seminal contribution, Frankel [11] argues that monetary policy and in particular interest rates are key determinants of developments in commodity prices. This author extends Dornbusch [4] exchange rate overshooting model to the case of commodity prices and using no arbitrage conditions explains the link between these two variables. Given commodity prices flexibility, the effect of monetary policy should be almost instantaneous and occur with an overshooting behaviour which is reversed in later periods. Frankel claims that an increase in nominal money supply must be matched by a proportional change in the general price level. However, since a proportion of prices is sticky in the short run, there is a short-term decline in real interest rates. This decrease leads to an increase in commodity prices through the following channels.

(1) On the supply side, a decline in real interest rates generates incentives to delay the extraction of raw materials, as the cost of holding inventories in the ground also decreases.

(2) Additionally, it provides incentives for carrying inventories, due to the lower implied opportunity cost of storage.

(3) Furthermore, it encourages investors to buy contracts of futures and other derivatives related to commodity prices, increasing their demand for such products.

An additional channel, identified by Arango et al. [12], is related to how low interest rates increase demand for capital goods which use commodities as inputs pushing basic goods prices up.

The fact that commodity prices respond more than proportionally to movements in the monetary policy rate is explained following Dornbusch's overshooting model once the exchange rate for commodity prices is replaced. The basic idea of this approach is that commodity prices will overshoot their equilibrium levels in response to a monetary policy shock. Therefore, a decline in real interest rates increases commodity prices above their equilibrium in the short run. As a result, firms build up inventories and new investment projects become profitable, thus increasing commodity supply while simultaneously demand for commodity futures decreases as investors believe the price is above equilibrium. During this correction, the aggregate price level moves in the same direction as the movement in commodity prices.

In summary, the literature has identified three fundamental determinants of commodity prices. First, since many commodities are inputs in the production process, both demand and prices usually increase with global economic activity. The second factor is the exchange rate since commodity prices are denominated mostly in US dollars and commodity exporters have an incentive to stabilize their income and raise prices when the dollar is weak. Furthermore, a depreciation of the dollar means lower commodity prices in local currency and a consequent increase in the demand of such goods which pushes up prices. The third factor is the monetary policy and its effect on prices. Lower interest rates decrease the incentive to extract today, increase the incentives to maintain inventories, and stimulate the demand for commodity derivatives, all of which raise the prices of basic products.

2.2. Empirical Results in the Literature. This subsection reviews recent empirical literature on the relationship between interest rates and commodity prices. According to Frankel [5], there is a negative relationship between real 
interest rate and real commodity prices. In particular, if the interest rate increases by 100 basis points, commodity prices drop by $6 \%$ (this evidence holds for the three commodityprice measures that Frankel studies: CRB, Dow Jones and Moody's.).

According to Akram [13], an explanation for the possible weakness in the relationship may be the need to control for macroeconomic variables like real exchange rate and economic activity when analyzing the relationship between commodities and interest rates. This author argues that the solution to the problem is to carry out an analysis which includes the monetary policy endogenously (see also [6]). There is an endogeneity in the relationship between commodity prices and interest rates, because low interest rates mean higher commodity prices and high commodity prices can lead to future increases in aggregate price indices and a contractionary monetary policy. Hence, it is considered more appropriate to develop a multivariate analysis to capture this and other endogenous relationships. In this sense, Flórez [6] introduces a Taylor rule in Frankel's approach and, using an SVAR, finds that, for a $1 \%$ increase in interest rate, commodity prices fall between $2.8 \%$ and $5.9 \%$. In the opposite direction, an increase in commodity prices of $1 \%$ leads to higher interest rates from $0.2 \%$ to $0.5 \%$. Furthermore, Flórez finds that in recent years the effect on commodity prices has a lag.

Reference [13] also argues that in addition to the transmission mechanisms explained by Frankel, there is an indirect channel from which the interest rate affects the price of commodities through the exchange rate. According to uncovered interest parity, the exchange rate variation depends on the interest rate differential between an economy and its international benchmark. Thus, the interest rate affects the exchange rate and the exchange rate in turn has an effect on the price of commodities.

While Frankel uses arbitrage conditions to develop his model, Browne and Cronin [14] examine the relationship between commodity prices, consumer goods prices, and the money supply in a pure-exchange economy framework. This paper examines whether an exogenous change in money supply causes price disequilibrium in both commodity and consumer goods markets and how measures of both of these disequilibria can predict future changes in CPI inflation. Browne and Cronin [14] find that commodity and consumer prices are cointegrated with the money stock and move proportionally to it in the long run. Additionally, they find that commodity prices overshoot their new equilibrium level in response to a money shock, while consumer prices adjust more slowly and do not overshoot. Finally, the deviation of commodity prices from their long-run values has explanatory power for subsequent CPI inflation.

Similar findings are reported by Anzuini et al. [8]. These authors perform a structural VAR estimation (SVAR) which allows identifying monetary policy shocks by assuming structural restrictions on their contemporaneous impact on the system. Their results show that the monetary effects on aggregate commodity prices are significant and that the short-run response usually has an overshooting during the first year after the shock. This paper also finds that the main transmission channel is the effect of the shock on inflation and growth expectations. We follow this paper and related literature on the procedure to identify monetary policy shocks.

On the other hand, Lombardi et al. [15] estimate a VAR augmented by factors (FAVAR), in which the factors are two common trends in prices of commodities particularly food and metals. With this structure they study the impulse response between the price of commodities, the common trends, the exchange rate, the economic activity, oil prices, and interest rates. According to the authors, the exchange rate, economic activity, and the common trends have a major impact on commodity prices. However, any significant relation between oil prices and interest rates is not found, and this result contradicts the hypothesis of Frankel. A similar result is found in Frankel and Rose [16]. These authors estimate panel-data regressions of several individual commodity prices which are explained by both macroeconomic and microeconomic determinants. While inventory indicators and global GDP are found to be important determinants, the effect of the real interest rate is found to be nonsignificant. These estimations are based on a theoretical model which is an extension of the model presented in Frankel [5].

Overall, the literature has several studies that try to empirically verify the hypothesis of Frankel [11]. These papers have usually applied multivariate methods such as vector autoregressive models (VAR) or vector error correction models (VEC) in presence of cointegrating relationships or the imposition of structural restrictions (SVAR, SVEC). However, there is still no consensus in the literature about empirical relevance of Frankel's hypothesis. The purpose of this paper is to provide some evidence on the relationship of commodity prices and monetary policy for individual prices.

\section{Theoretical Model and Econometric Approach}

3.1. Basic Model. Frankel's theory builds on the work of Dornbusch [4] overshooting model but substitutes the exchange rate by commodity prices. The reason for the overshooting is that basic product prices adjust rapidly, while most other prices do it slowly. This model implies a negative relationship between the real interest rate and the difference between the spot price of a commodity and its expected equilibrium price over time.

Assume $s$ is the log-spot price of a commodity, $\bar{s}$ is the long-term equilibrium price, $p$ is the log-price level of the economy, $q \equiv s-p$ is the real commodity prices, and $\bar{q}$ is the real long term equilibrium of commodity prices. When market participants note that the real price of commodities is above or below its long-term perceived value, they expect it to fall back to its equilibrium, at a rate proportional to this gap:

$$
\begin{gathered}
E[\Delta(s-p)] \equiv E[\Delta q]=-\theta(q-\bar{q}) \\
E(\Delta s)=-\theta(q-\bar{q})+E(\Delta p) .
\end{gathered}
$$

On the other hand, agents face the decision to hold the product for another period (without extracting or harvesting 

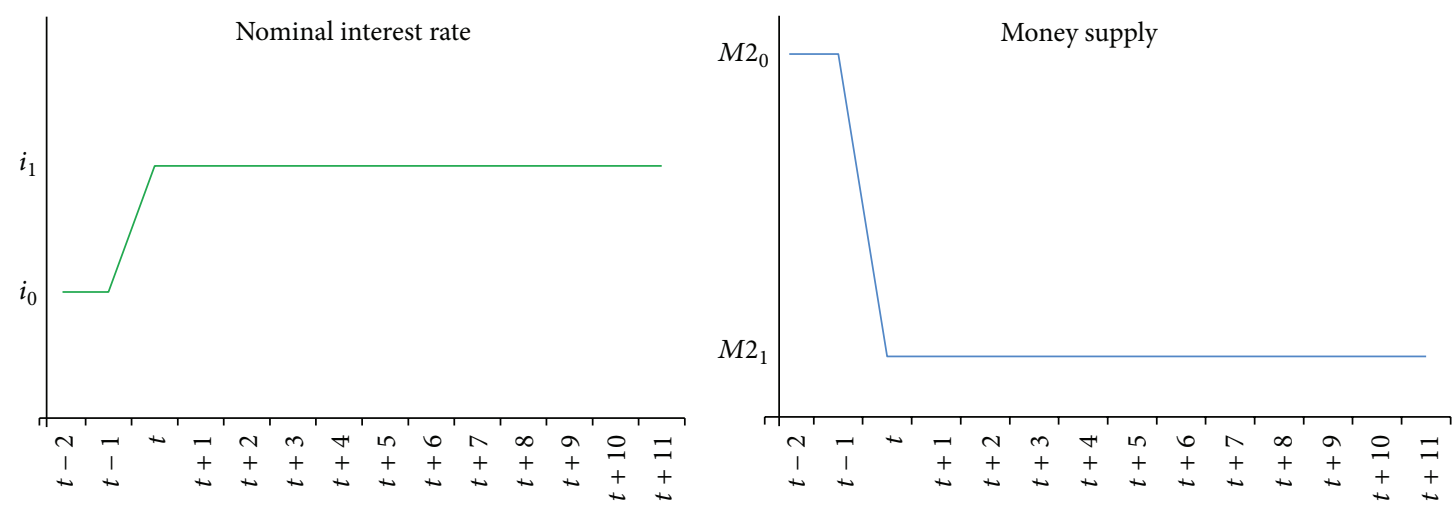

FIGURE 1: Frankel effect example (a).

it or keeping it in inventory) or sell it at today's prices and deposit the money in the bank to earn interest. The arbitrage condition arises when the expected rate of return to these two alternatives is the same:

$$
\begin{gathered}
E[\Delta s]+c=i, \\
c \equiv \mathrm{cy}-\mathrm{sc}-\mathrm{rp},
\end{gathered}
$$

where $c$ is the net profit from holding an inventory of the product, cy is the convenience yield from holding the stock (eg gold), sc is the storage cost, and rp is the risk premium. By combining (2) and (3) we obtain

$$
\begin{gathered}
-\theta(q-\bar{q})+E(\Delta p)+c=i, \\
q-\bar{q}=-\left(\frac{1}{\theta}\right)(i-E(\Delta p)-c) .
\end{gathered}
$$

According to (5) real commodity prices (measured in relation to its long-run equilibrium) are inversely proportional to the real interest rate (measured against a constant term that depends on $c$ ). When the real interest rate is high, as in the 1980s, money flows outside the commodity sector in the form of foreign currency, emerging markets assets, and other securities. Only when commodity prices are perceived to be sufficiently below the equilibrium the arbitrage condition is fulfilled. By contrast, when the real interest rate is low, as in 2001-04, money flows into the commodity market.

\subsection{The Effect of Monetary Policy on Commodity Prices.} Frankel [11] explains the overshooting model as follows: suppose that there is an increase in the nominal interest rate or an equivalent drop in money supply which is expected to be permanent (see Figure 1).

Then in the long run all prices should fall in the same magnitude. However given that in the short run manufacture prices are fixed, the rise in the nominal interest rate generates a reduction in real money supply. To equilibrate the money demand, real interest rate has to decrease (see Figure 2 and [6]).

Now, since commodity goods are storable, they should follow the arbitrage condition (the rate of return on treasury bills can be no greater than the expected rate of increase of commodity prices minus the storage cost). Then commodity prices must fall today by more than the contraction in money supply [6]. This fall in commodity prices is such that it generates expectations of future appreciation that incentive firms to hold inventories despite the high storage cost.

\section{"In the long run, the general price level adjusts to the change in money supply. As a result, the real money supply, real interest rate, and real commodity prices eventually return to where they were", Frankel [5] page 5.}

The reason for the overshooting in commodity prices is their rapid adjustment, while most other prices adjust slowly (Figure 3); see Bordo [17] and Frankel [3] for further discussion.

Within this framework, we estimate a structural VAR model (SVAR) which captures the relationship between the price of oil, gold, coal, and nickel with their macroeconomic determinants. Structural restrictions on the contemporaneous effects of innovations are used to identify monetary policy shocks using information from the interest rate and from the monetary aggregate of the US. Our identification strategy follows $[9,10]$. The remaining determinants are the trade weighted exchange rate of the US, the consumer price index for the US, and a global economic activity index (the advantage of using a SVAR framework with both interest rates and $M 2$ is that this strategy takes in account the endogenous response of monetary policy to general developments in the economy. These endogenous responses can amplify the initial policy movement).

3.3. Data. We use quarterly data from 1980Q1 to 2010Q3. The international prices of oil, coal, gold, and nickel are retrieved from the IMF commodity database, and we also use Commodity Research Bureau aggregate price index. Given the fact that we do not have a global monetary policy measure, we use nominal M2 from the United States and the Federal Funds Rate simultaneously. For the global economic activity variable we use quarterly GDP data from IMF between 2000 and 2010. For the 1980-2000 period we construct a moving weighted average of the annual GDP growth of the world major economies: the United States, the Eurozone, Japan, UK, China, and India (these economies together account for $65 \%$ 


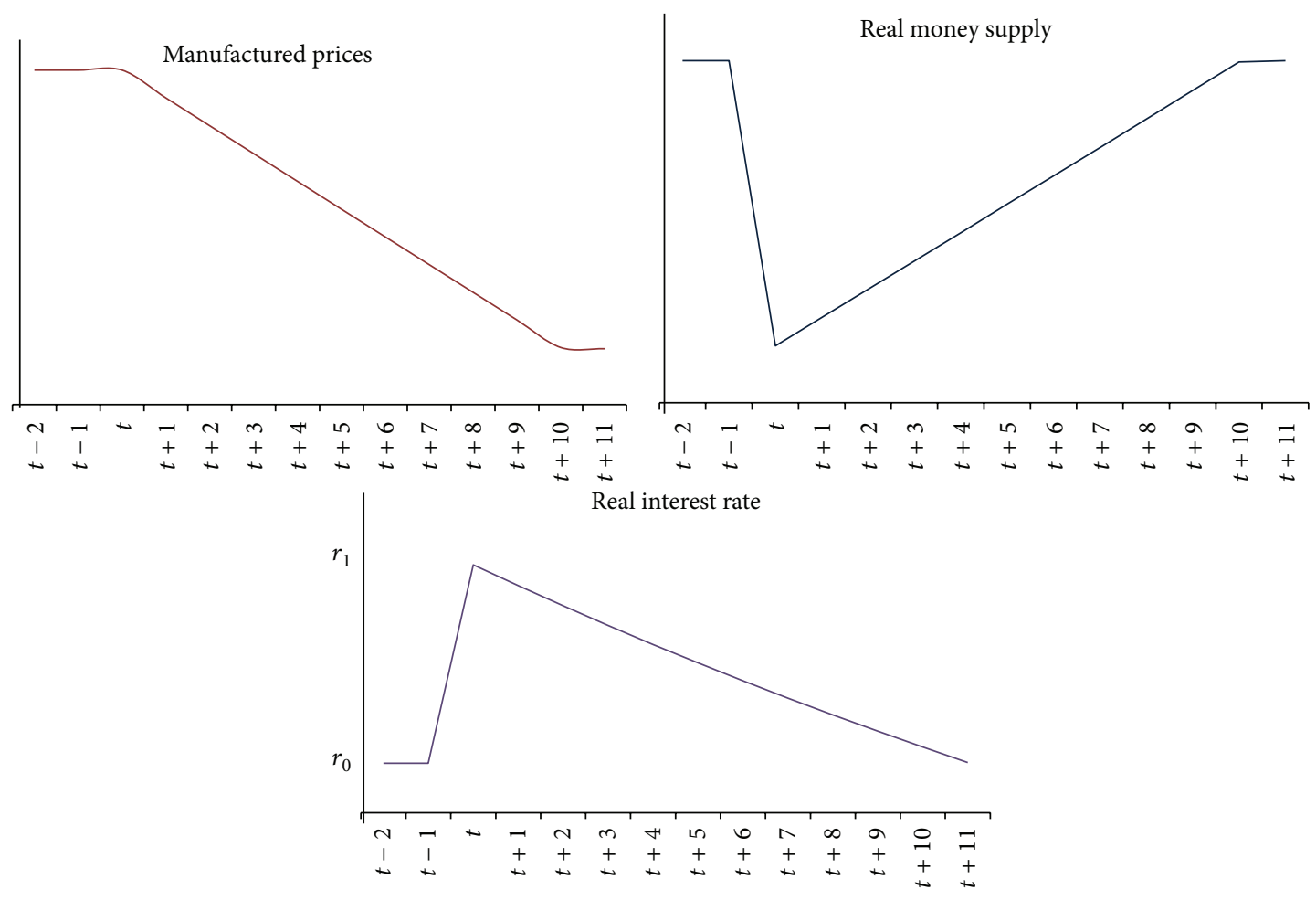

Figure 2: Frankel effect example (b).

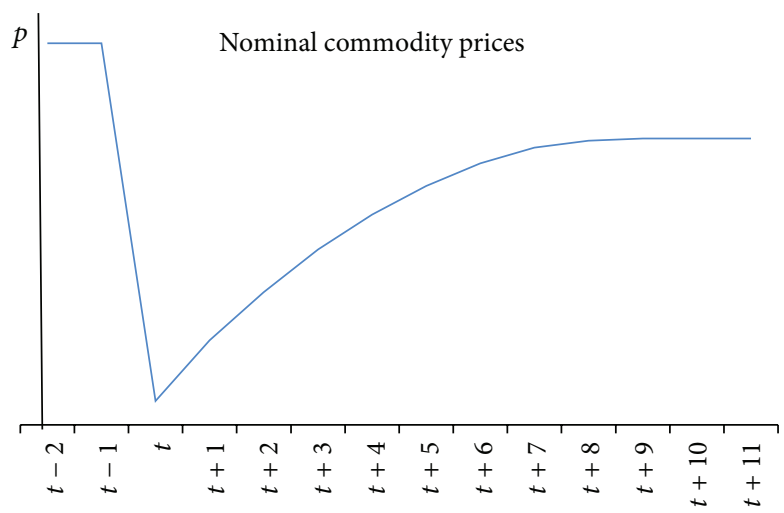

Figure 3: Frankel effect example (c).

of world GDP). We also use the US GDP from the Bureau of Economic Activity. Finally, we use the logarithm of the exchange rate against US trading partners. Figure 4 shows the series in the database.

3.4. Econometric Approach. We use a structural VAR technique based on the next equation:

$$
A X_{t}=A_{1}^{*} X_{t-1}+A_{2}^{*} X_{t-2}+\cdots+A_{p}^{*} X_{t-p}+\varepsilon_{t} .
$$

With $A_{j}^{*}=A A_{j}, j=1, \ldots, p$, and $\varepsilon_{t}=A u_{t} \sim$ $\left(0, \Sigma_{\varepsilon}=A \Sigma_{u} A^{\prime}\right)$. In (6), $\Sigma_{\varepsilon}$ has a diagonal covariance matrix with the advantage to model the economic contemporaneous relationships in $X_{t}$ using the matrix $A$.
Following Kim [10] and Anzuini et al. [8], in our first group of estimations, we take $X_{t}$ and $A$ as follows:

$$
X_{t}=\left[\begin{array}{c}
\mathrm{FFR}_{t} \\
M 2_{t} \\
\mathrm{CPI}_{t}^{\mathrm{US}} \\
\mathrm{GDP}_{t}^{\mathrm{US}} \\
P_{t}^{\mathrm{com}}
\end{array}\right], \quad A=\left[\begin{array}{ccccc}
1 & a_{12} & 0 & 0 & a_{15} \\
a_{21} & 1 & a_{23} & a_{24} & 0 \\
0 & 0 & 1 & a_{34} & 0 \\
0 & 0 & 0 & 1 & 0 \\
a_{51} & a_{52} & a_{53} & a_{54} & 1
\end{array}\right],
$$

where FFR is the federal funds rate, M2 is the US monetary aggregate, $\mathrm{CPI}^{\mathrm{US}}$ is the US consumer price index, 

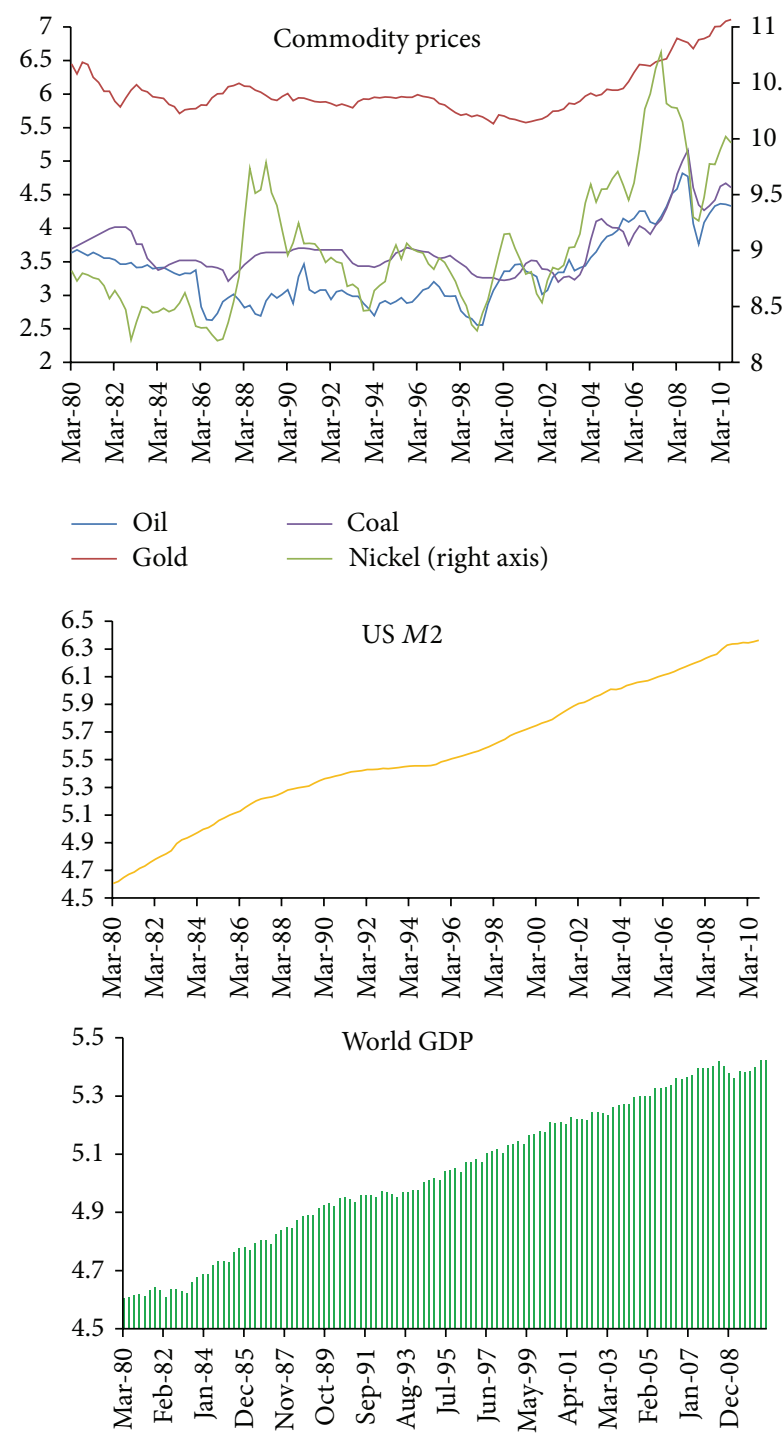

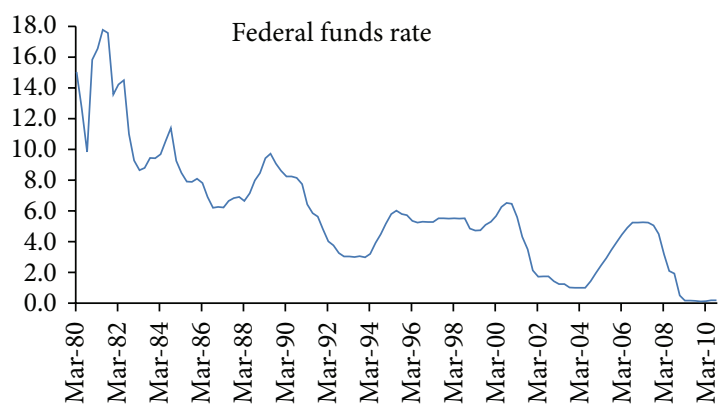

US GDP
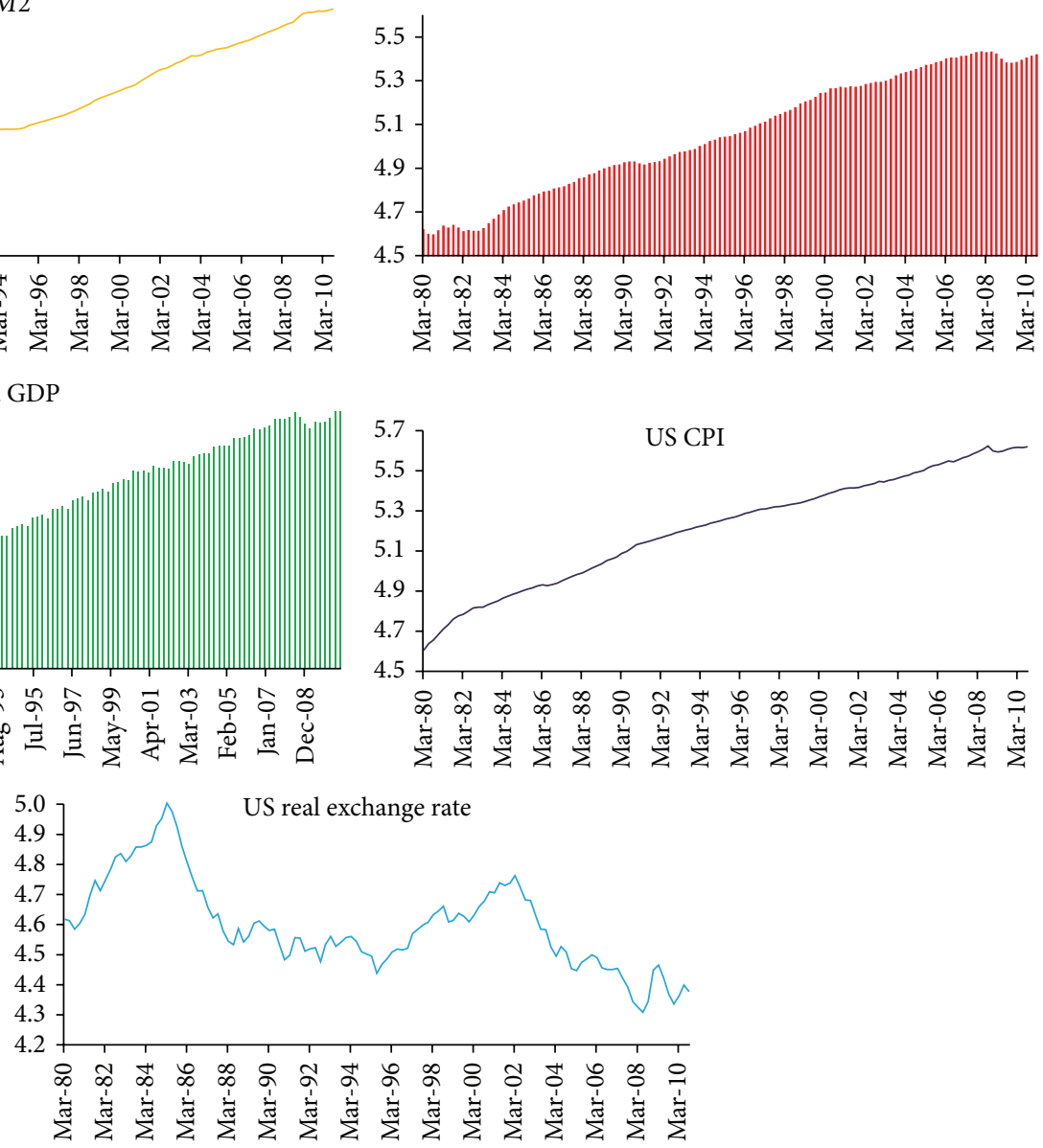

FIGURE 4: Data series considered in the models.

$\mathrm{GDP}^{\mathrm{US}}$ is the US gross domestic product, and $P^{\text {com }}$ corresponds to the commodity price considered that is replaced in each estimation by oil, gold, coal, and nickel prices, respectively. All variables except FFR are taken in logarithms.

According to Anzuini et al. [8], the first row of matrix $A$ is a money supply equation modelled as a reaction function of the monetary authority. Here it is assumed that, due to an informational delay, the current levels of prices and production are not available to the monetary authorities.
The second row is a money demand equation. The demand for money is a function of real income, the opportunity cost of holding money, and the nominal interest rate. The third and fourth rows encapsulate the hypothesis of price stickiness and adjustment costs; real activity is assumed to respond only with a lag to innovations on the system of variables. Finally, the last equation is and arbitrage equation which describes equilibrium in the commodity market as a financial market equilibrium. The commodity price is affected contemporaneously by all variables. 
Our second group of estimations considers an extended system of variables given as follows:

$$
X_{t}=\left[\begin{array}{c}
\mathrm{FFR}_{t} \\
M 2_{t} \\
\mathrm{CPI}_{t}^{\mathrm{US}} \\
\mathrm{GDP}_{t}^{\text {tot }} \\
E_{t}^{\mathrm{US}} \\
P_{t}^{\mathrm{com}}
\end{array}\right], \quad A=\left[\begin{array}{cccccc}
1 & a_{12} & 0 & 0 & 0 & a_{15} \\
a_{21} & 1 & a_{23} & a_{24} & 0 & 0 \\
0 & 0 & 1 & a_{34} & 0 & 0 \\
0 & 0 & 0 & 1 & 0 & 0 \\
a_{51} & a_{52} & a_{53} & a_{54} & 1 & 0 \\
a_{61} & a_{62} & a_{63} & a_{64} & a_{65} & 1
\end{array}\right] .
$$

The analysis is extended to include the rest of the world GDP and $E_{\mathrm{US}}$, in the first place, world economic growth, with a substantial contribution from emerging economies in recent years, is the main determinant of commodity demand and therefore of their price. Second, as many commodities are priced in dollars in international markets, a fall in the value of the dollar may raise the purchasing power and commodity demand of foreign consumers, while reducing the returns of foreign commodity suppliers and potentially their supply [13]. In this case, we model contemporaneous relationships between the variables based in Kim [10]. This approach has similar structure to the matrices used in the model with US data.

The new variables are in the fourth and fifth rows of $A$ in (8). The assumptions on the rest of the system are the same as in (7). On the other hand, we assume that all currently available information on the real economy and on the monetary policy stance affects the exchange rate instantaneously.

To compare the results with the literature, we also compute an estimation with a system in which $X_{t}[6,1]$ corresponds to the CRB index. Further analysis is discussed in next section.

3.4.1. Impulse Response Functions and Forecast Error Variance Decomposition. Within the estimation of the SVAR, it is possible to analyse the impulse response functions, compute the relevant multipliers, and then interpret the dynamic effects in the variables of an isolated and independent shock.

These functions can be expressed in terms of the MA representation of the SVAR equation (in this case (6)) as follows:

$$
X_{t}=\sum_{i=0}^{\infty} \Theta_{i} \varepsilon_{t-i},
$$

where $\Theta_{i}=\phi_{i} \mathbf{A}^{-1}$ and $\varepsilon_{t}=A u_{t}$.

In (9), $\Theta_{j k, i}$ represents the effect of a variable $j$ innovation in the variable $k i$ periods after the shock. This effect allows us to determine if there exists a significant relationship among the considered variables and if there is an overshooting behaviour in commodity prices in the system.

Furthermore, in Section 4, the forecast error variance decomposition of the model is also shown. This approach
TABLE 1: Unit root tests.

\begin{tabular}{lcccc}
\hline Variable & ERS & KPSS & $\begin{array}{c}\text { Ng } \\
\text { Perron }\end{array}$ & Model \\
\hline Federal funds rate & I (1) & I (1) & I (1) & Constant and trend \\
Exchange rate & I (1) & I (1) & I (1) & Constant \\
World GDP & I (1) & I (1) & I (1) & Constant \\
US GDP & I (1) & I (1) & I (1) & Constant and trend \\
M2 & I (1) & I (1) & I (1) & Constant \\
Coal price & I (1) & I (1) & I (1) & Constant \\
Nickel price & I (0) (I (1) & I (1) & I (1) & Constant and trend \\
Oil price & with 1\%) & & & \\
Gold price & I (1) & I (1) & I (1) & Constant and trend \\
CRB index & I (1) & I (1) & I (1) & Constant and trend \\
US CPI & I (1) & I (1) & I (1) & Constant and trend \\
\hline
\end{tabular}

is also developed from (9), where the forecast error $h$ steps ahead is provided by

$$
X_{t+h}-X_{t(h)}=\sum_{i=0}^{h-1} \Theta_{i} \varepsilon_{t+h-i},
$$

where $X_{t}(h)$ is the forecast $h$ steps ahead, conditional to information in $t$. Let $\theta_{m n, i}$ be the $m n$th element of $\Theta_{i}$, and the $h$-step forecast error of the $j$ th element of $X_{t}$ is given as follows:

$$
\begin{aligned}
x_{j, t+h}-x_{j, t}(h) & =\sum_{i=0}^{h-1}\left(\theta_{j 1, i} \varepsilon_{1, t+h-i}+\cdots+\theta_{j K, i} \varepsilon_{K, t+h-i}\right) \\
& =\sum_{k=1}^{K-1}\left(\theta_{j k, 0} \varepsilon_{k, t+h}+\ldots+\theta_{j k, h-1} \varepsilon_{k, t+1}\right) .
\end{aligned}
$$

Then, if coefficients are significant, the forecast error of the $j$ th component depends upon all innovations (this significance is also related to the Granger and instantaneous causality among the variables) in the system. Thus, from (11) it is possible to obtain the proportion of the $h$-step forecast error variance of $j$ accounted for by $\varepsilon_{k t}$ innovations; such concept helps to build an idea of the most relevant variables among the system with respect to another $j$ variable. This procedure is done with all the variables of the system regarding the prices of each commodity and the results are shown in the next section.

\section{Results}

Several unit root test statistics (Ng-Perron, KPSS, ERS) were computed to each of the variables considered. The results (see Table 1) show no evidence against the hypothesis that there is a unit root in the variables in levels (Johansen's cointegration trace test statistic indicates the presence of cointegration among the variables in all the models estimated (see Tables 4 and 5)). Using Akaike, Schwarz, Hanna-Quin, 

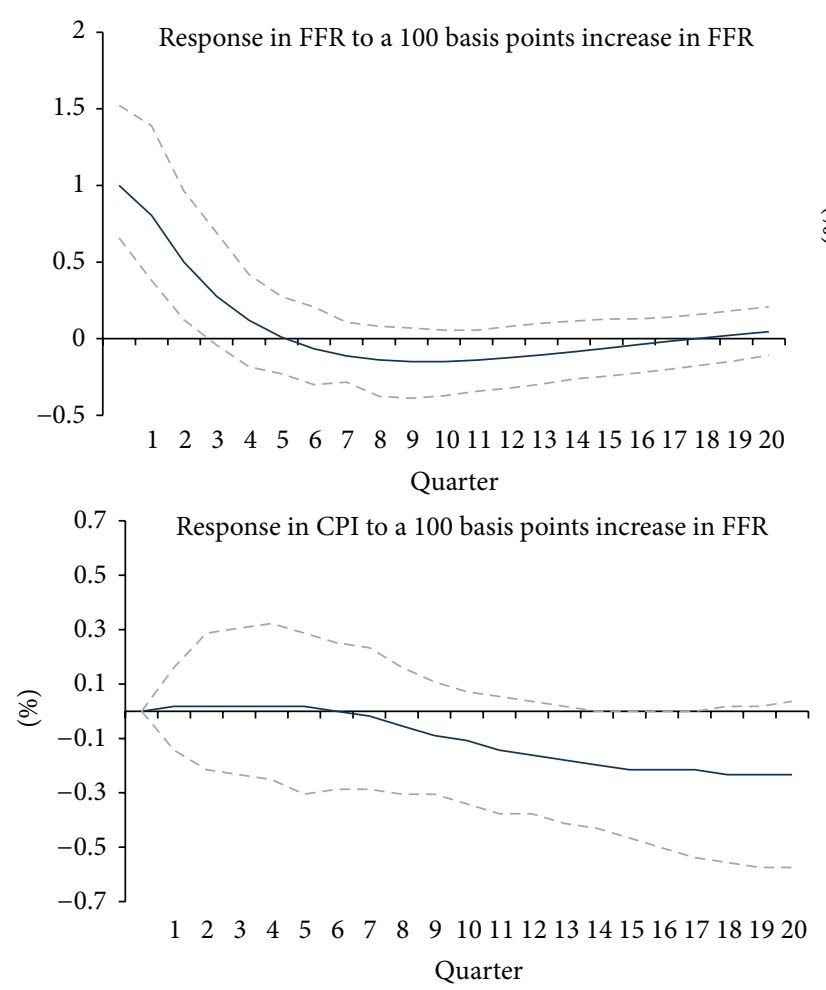
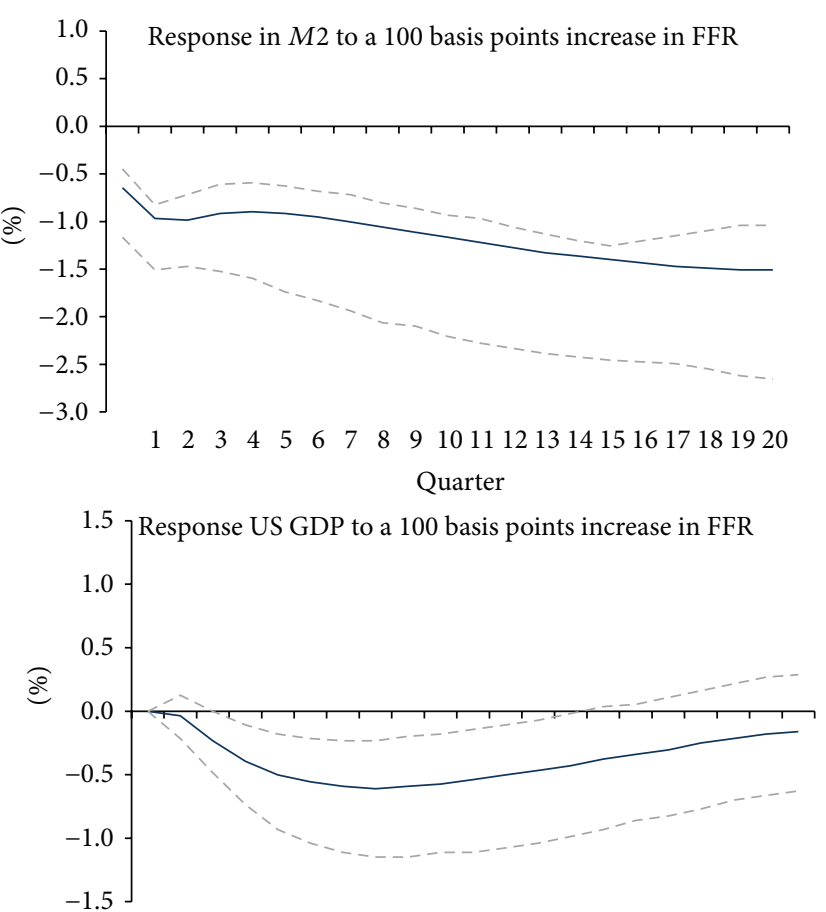

$1 \quad 2 \quad 3 \quad 4 \quad 5 \quad 6 \quad 7 \quad 8 \quad 9 \quad 1011121314151617181920$ Quarter

FIGURE 5: Impulse response functions of the system of variables to a shock in the FFR.

TABLE 2: Information criteria for SVAR models.

\begin{tabular}{lccccc}
\hline \multicolumn{5}{c}{ Optimal endogenous lags from information criteria } \\
VEC models & FPE & AIC & SC & HQ & Number of lags chosen \\
\hline Oil & 10 & 10 & 2 & 3 & 2 \\
Gold & 10 & 10 & 2 & 2 & 2 \\
Coal & 10 & 10 & 2 & 2 & 2 \\
Nickel & 10 & 10 & 2 & 2 & 2 \\
\hline
\end{tabular}

TABLE 3: Information criteria for SVAR models (amplified system).

\begin{tabular}{lccccc}
\hline \multicolumn{5}{c}{ Optimal endogenous lags from information criteria } \\
Var models & FPE & AIC & SC & HQ & Number of lags chosen \\
\hline Oil (and average) & 10 & 10 & 2 & 2 & 2 \\
Gold & 10 & 10 & 2 & 2 & 2 \\
Coal & 10 & 10 & 2 & 2 & 2 \\
Nickel & 10 & 10 & 2 & 2 & 2 \\
CRB & 10 & 10 & 2 & 2 & 2 \\
\hline
\end{tabular}

and Final Prediction Error information criteria and considering the presence of autocorrelation we chose VAR(2) models for every specification (see Tables 2, 3, and 6).

4.1. Structural VAR Estimation with US Data. In this section, we analyse impulse response functions based on estimations of (7) with 95\% confidence intervals following Hall [18] approach. Figures 5 and 6 show the dynamic response to a 100 basis points increase in the Federal Funds Rate for the system
TABLE 4: Cointegration trace test.

\begin{tabular}{llllll}
\hline \multicolumn{7}{l}{ Cointegration analysis: trace test } \\
VEC models & $r=0$ & $r=1$ & $r=2$ & $r=3$ & $r=4$ \\
\hline Oil & 0,000 & 0,009 & 0,077 & 0,199 & 0,885 \\
Gold & 0,010 & 0,906 & 0,006 & 0,083 & 0,466 \\
Coal & 0,000 & 0,025 & 0,013 & 0,210 & 0,746 \\
Nickel & 0,000 & 0,070 & 0,001 & 0,064 & 0,182 \\
\hline
\end{tabular}

TABLE 5: Cointegration trace test (amplified system of variables).

\begin{tabular}{lcccccc}
\hline \multicolumn{7}{c}{ Cointegration analysis: trace test } \\
VAR models & $r=0$ & $r=1$ & $r=2$ & $r=3$ & $r=4$ & $r=5$ \\
\hline Oil & 0,000 & 0,000 & 0,000 & 0,003 & 0,036 & 0,814 \\
Gold & 0,000 & 0,000 & 0,000 & 0,005 & 0,040 & 0,115 \\
Coal & 0,000 & 0,000 & 0,000 & 0,001 & 0,057 & 0,920 \\
Nickel & 0,000 & 0,000 & 0,001 & 0,013 & 0,108 & 0,753 \\
CRB & 0,000 & 0,000 & 0,004 & 0,050 & 0,180 & 0,627 \\
\hline
\end{tabular}

that considers oil price. All responses have the expected signs, and a contractionary shock in the interest rate reduces the monetary aggregate, has a negative and significant impact on prices after several quarters, and, with a lag of three periods, decreases US GDP for nine quarters.

In response to a shock in FFR, oil price displays a negative and strong reaction. Our results support an overshooting behaviour of oil price, the response reaches its peak in the second quarter $(-11.8 \%)$, and in the long run the effect slowly 


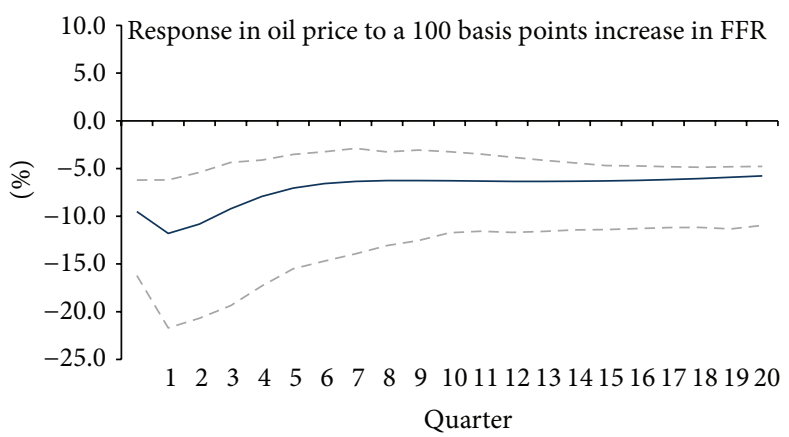

FIGURE 6: Oil impulse response to a shock in FFR.

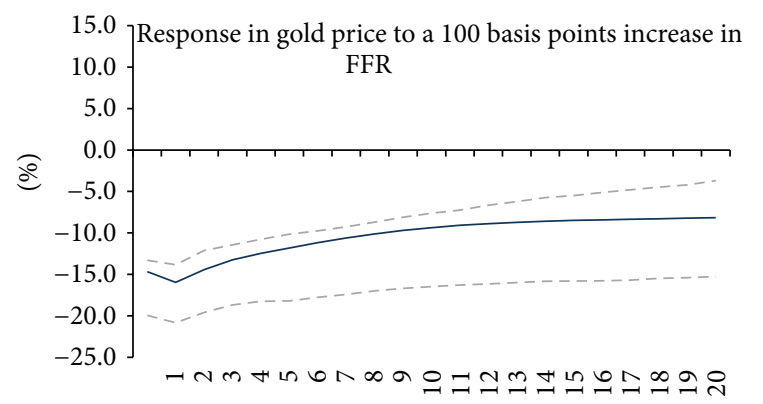

Quarter

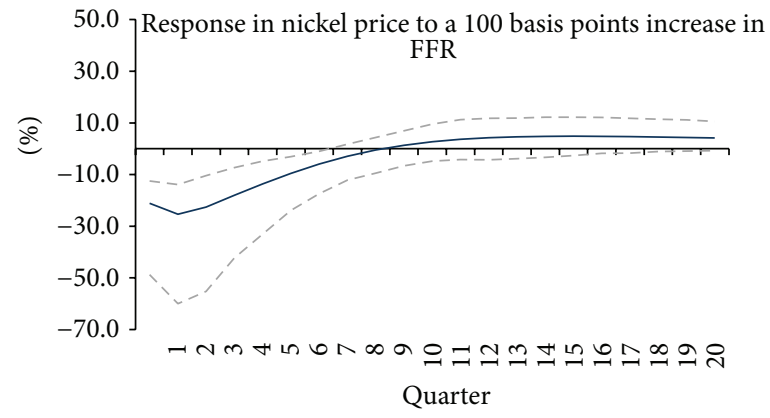

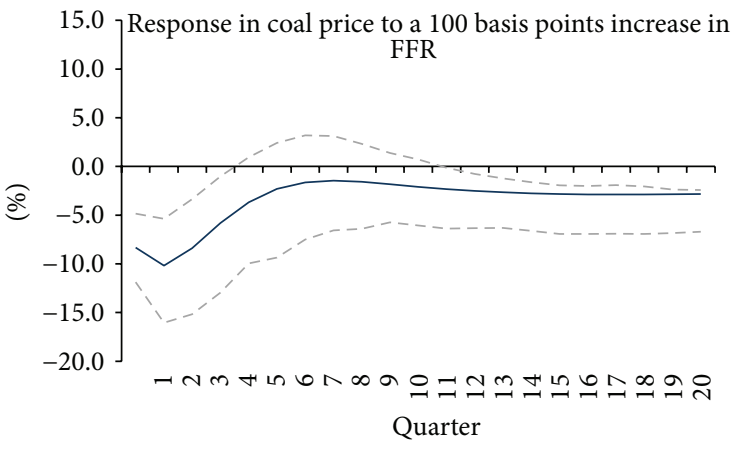

Quarter

FIGURE 7: Response of individual prices.

TABLE 6: Residual tests.

\begin{tabular}{lcc}
\hline & Autocorrelation Portmanteau test (16 lags) & \\
Model & Statistic & $P$ value \\
\hline Oil & 347,90 & 0,522 \\
Gold & 375,23 & 0,563 \\
Coal & 378,45 & 0,169 \\
Nickel & 345,14 & 0,142 \\
\hline Var models & Statistic & $P$ value \\
\hline Oil & 536,30 & 0,154 \\
Gold & 545,35 & 0,099 \\
Coal & 538,71 & 0,138 \\
Nickel & 544,04 & 0,105 \\
CRB & 563,795 & 0,033 \\
\hline
\end{tabular}

converges to $-5.7 \%$. As the effect on oil price is negative and significant and the CPI responds with a lag, there is a significant effect of monetary policy on relative prices.
However this effect is reabsorbed in the medium term when CPI decreases and the fall in oil prices converges to lower levels.

The impulse response functions showed in Figure 7 correspond to the system of variables in (7), where in each case commodity price is replaced by gold, coal, and nickel prices, respectively. The results for the three models display a strong and negative impulse response to a shock in FFR as predicted by theory. All prices have an overshooting behaviour and their strongest response is observed after the first quarter. Gold prices exhibit a significant and persistent fall with a maximum of $-16 \%$ in the short run and of $8 \%$ in the long run. With respect to coal price, the response peaked to $-10 \%$ and displays the less persistent behaviour returning to zero after the first year. In the case of nickel price, the response reaches a minimum of $25 \%$, and the effect is significant and takes two years to converge back to the baseline. Finally the response of the rest of variables is largely the same as in Figure 5 and is generally consistent with the theory. 

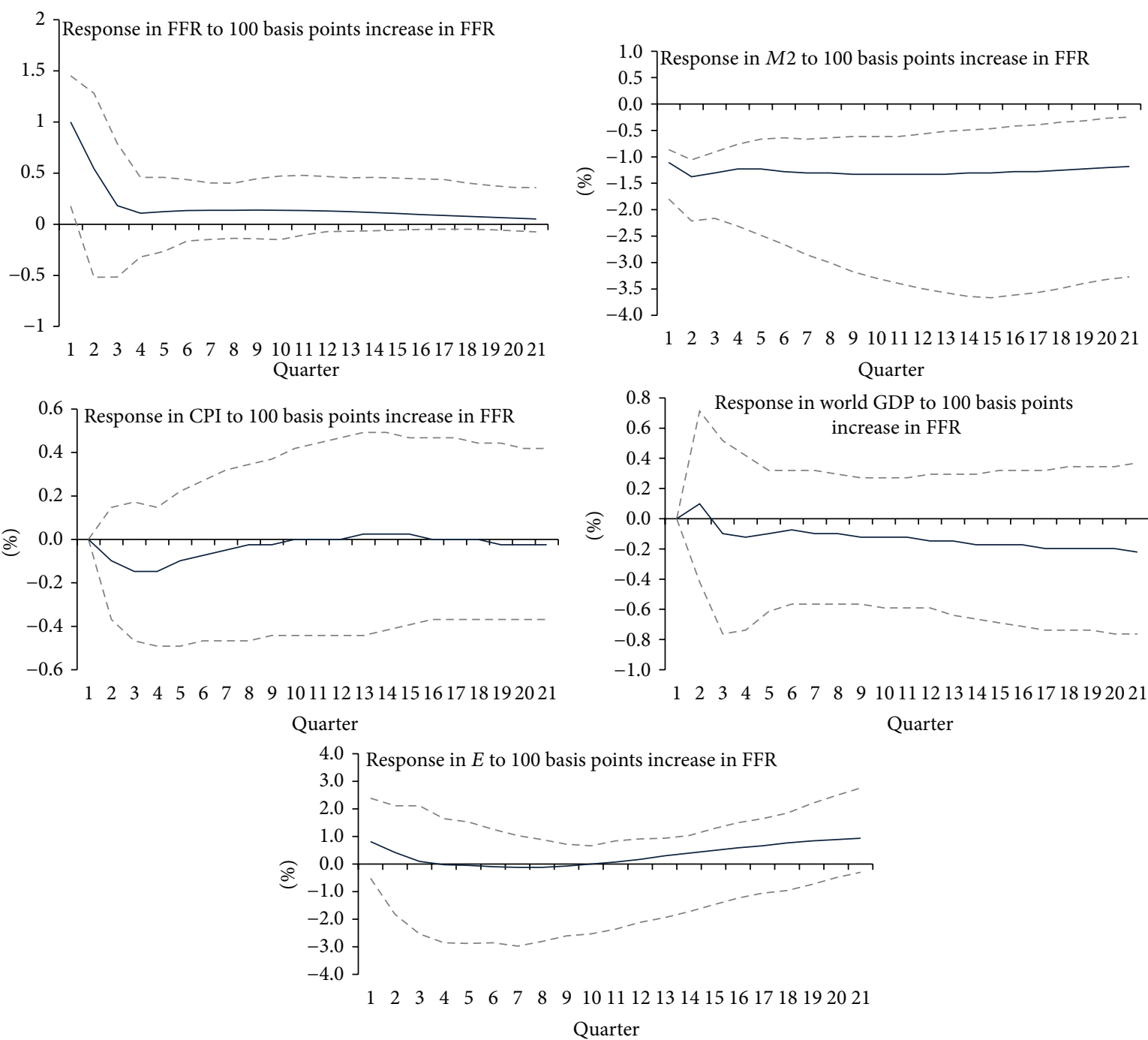

FIGURE 8: Impulse response functions of the system or variables to a shock in the FFR (amplified model).

4.2. Structural VAR Estimation with Augmented Model. In this section, the model is extended to include the effects of global output and the exchange rate in (8). As can be seen in Figures 8 and 9 all responses have the expected signs. First, a contractionary shock in the interest rate implies a significant reduction in the monetary aggregate. Responses on CPI and World GDP have the correct sign but are not statistically significant.

Similarly to the results in the basic model, in response to a shock in FFR, oil price displays a negative and strong reaction. There is also evidence of overshooting behaviour as the response reaches its peak in the second quarter $(-12,7 \%)$, and in the long run the effect slowly converges to approximately $-4,9 \%$.

Figure 10 shows the responses of the commodity price in each model (gold, coal, and nickel). The results for the coal and gold models display negative impulse responses to shocks in FFR which are slightly stronger than those in the basic model. In this case the nickel price response is not different from zero. The price of gold exhibits a significant

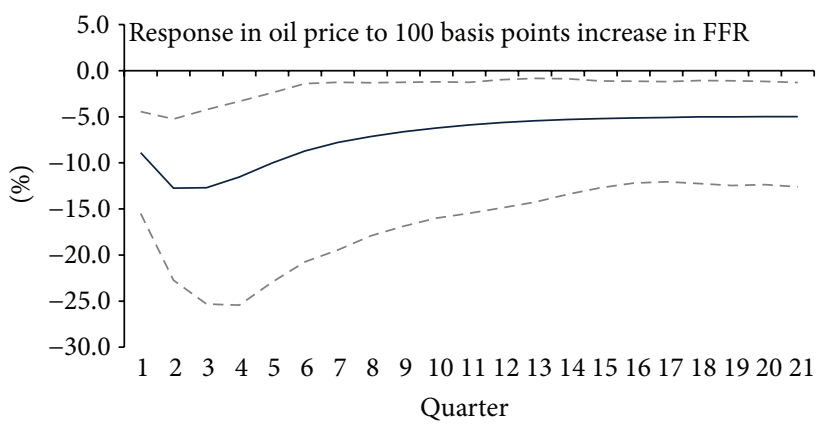

Figure 9: Oil impulse response to a shock in FFR.

and persistent fall with a maximum of $-18 \%$ in the short run which seems to converge to $-11 \%$, approximately, in the long run. The response of the price of coal peaks at $-12 \%$ and displays the low persistence since it returns to zero right 


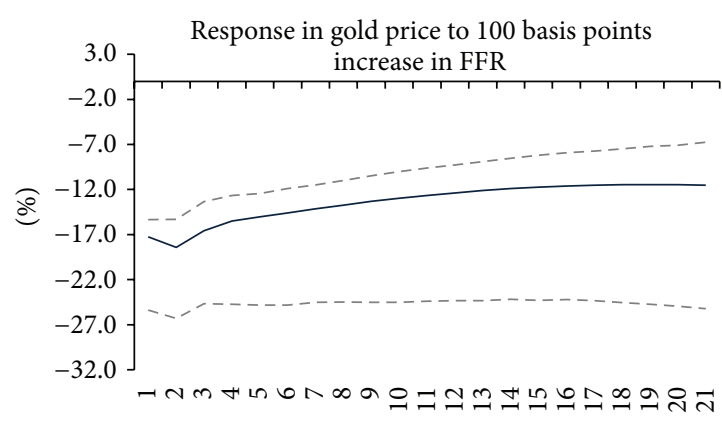

Quarter

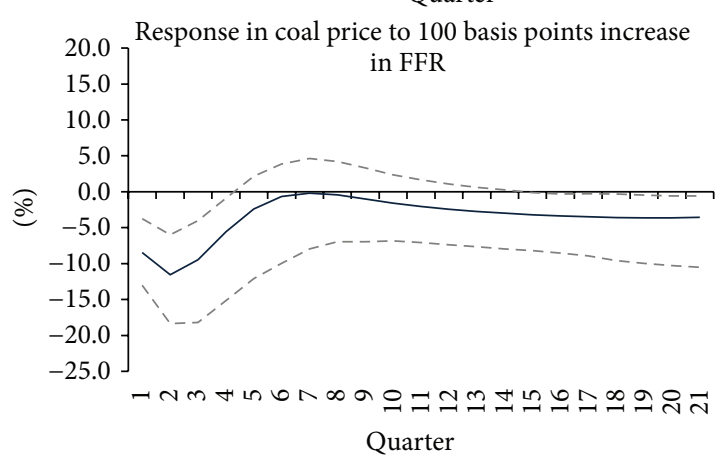

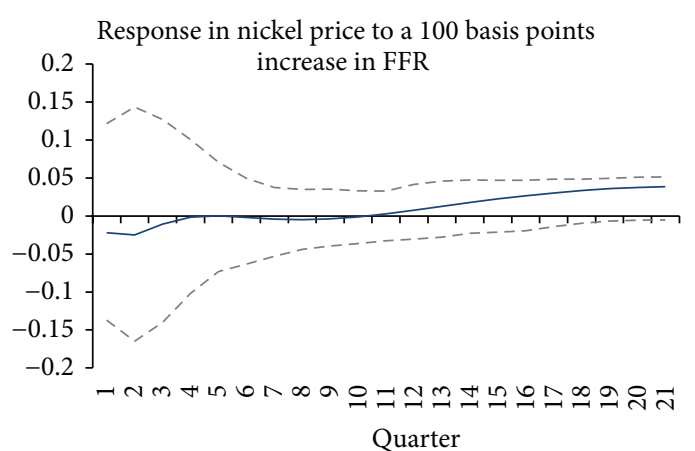

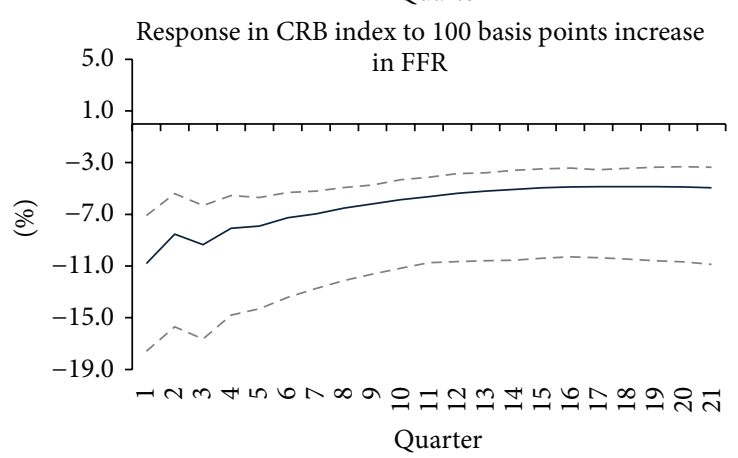

FIGURE 10: Response of individual prices and CRB index (amplified model).

after the first year. The response of the remaining variables is mostly the same and is generally consistent with the theory.

We also include a commodity-price index in our analysis in order to compare our results with related literature. The estimated response of the CRB price index to shocks in the FFR is also consistent with theory and peaks at $-11 \%$ in the first quarter and thereafter it converges slowly to $4.8 \%$. A similar effect on the aggregate commodity price index was found by Anzuini et al. [8] although the exchange rate was not included in the system that they estimated.

4.3. Variance Decomposition. We analyse forecast error variance decompositions of our set of commodity prices over a 20 -quarter forecasting horizons. It displays percentages of the variance of the prediction error made in forecasting a variable at a given horizon due to the six structural shocks which are identified in the structural restrictions described in (8).

Figure 11 shows the contribution of the structural disturbance related to monetary policy (FFR) shocks in explaining the fluctuations of commodity prices. These contributions vary, in the 20th quarter, from about $10 \%$ for coal to $40 \%$ for the CRB index (as mentioned in Section 3.4.1 it is not possible to make inference from the variance decomposition of nickel price due to the lack of significance in the impulse response coefficients). The second most important determinant of commodity price fluctuations, different from the price itself, also varies across commodities. It is the exchange rate for coal and the CRB (indeed, in the case of coal, the exchange rate is the most important determinant of volatility apart from the price itself). It is money-demand shocks (M2) in the case of gold. Finally, it is both World GDP and consumer-prices (CPI) in the case of oil.
From this exercise, we can conclude that overall structural monetary policy shocks are very important determinants of commodity price fluctuations. The exchange rate is also important to explain fluctuations in the aggregate commodity price index.

\section{Conclusion}

Numerous countries are frequently exposed to macroeconomic adjustment in response to the behavior of commodity prices. This process is generally exacerbated by the low degree of export diversification. In Colombia, oil, coal, nickel, and gold exports accounted for 64\% of 2010 exports, therefore understanding the behavior of commodity prices and their determinants is crucial for the analysis of economic activity.

This paper constitutes an econometric approach to the theoretical result which states that monetary policy has an impact on commodity prices, as proposed by Frankel [3]. Our analysis is based on structural VAR models, using $[9,10]$ monetary policy shocks identification scheme. Our main finding supports this theoretical argument and in contrast with the results of Anzuini et al. [8] we found that shocks in US monetary policy has a significant and large effect on Colombian export commodity prices (oil, coal, and gold).

In this document we perform two exercises, in the first one, following Anzuini et al. [8] the model consists of US FFR, $M 2, \mathrm{CPI}$, and GDP. In the second one, we extend the analysis to include other commodity prices determinants such as US exchange rate and the rest of the world GDP. In general, both results are supportive of each other; however, in the extended model prices response to monetary policy shock increased. 

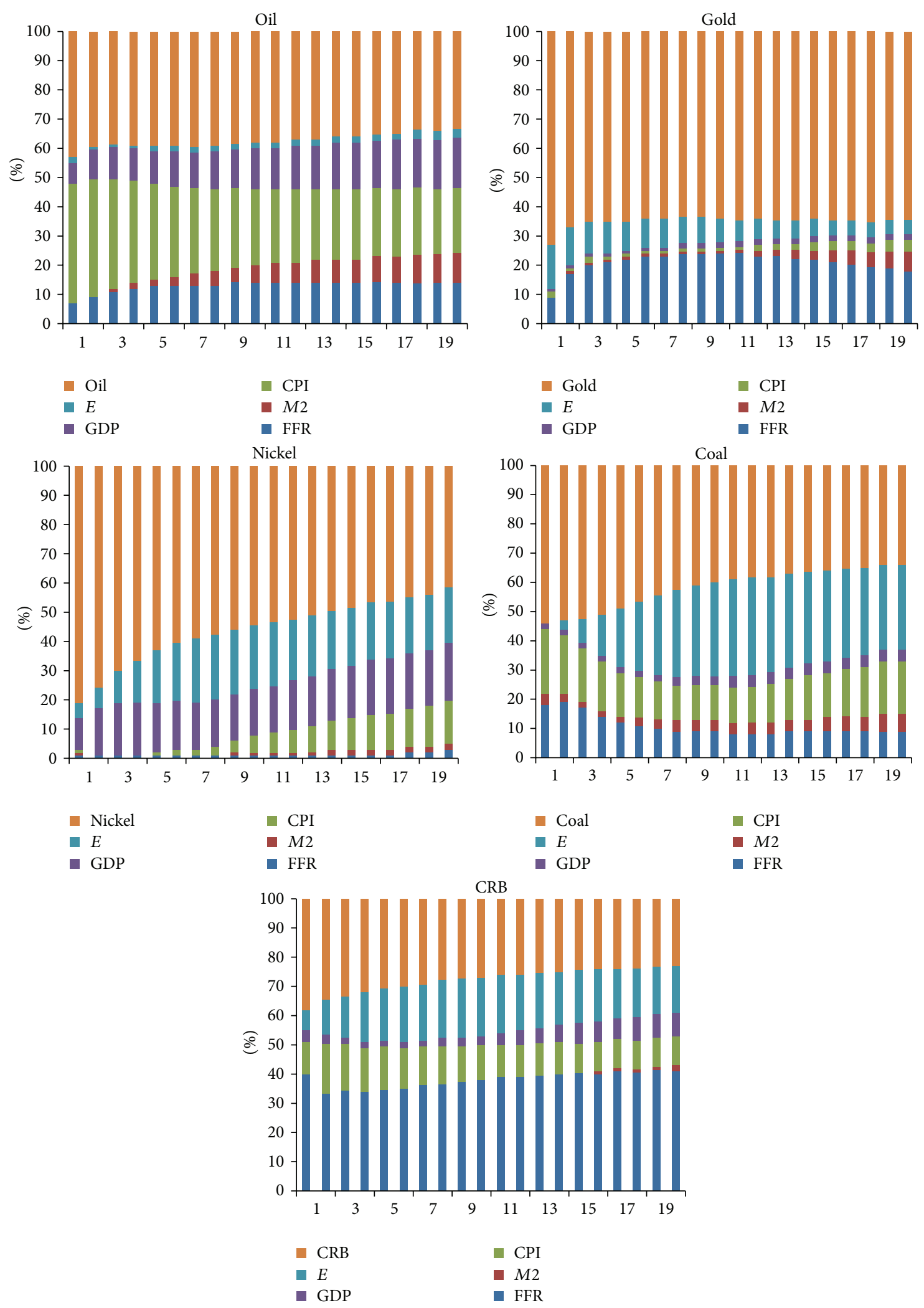

FIGURE 11: Forecast error variance decomposition for the SVAR models (amplified system). 
Our evidence suggests that shocks on US monetary policy contribute significantly to movements in commodity prices. A 100 basis points rise in FFR decreases oil price by $12.7 \%$, gold price by $18 \%$, coal price by $12 \%$, and CRB index by $11.1 \%$ in the short run. In contrast to the instantaneous reaction of the CRB index, Colombian exported commodities reach their maximum response to the shock on FFR with a lag of one quarter. In the same line, oil, coal, gold, and nickel prices have a slightly stronger overall response to monetary policy than what is found for aggregate indices (Anzuini et al. [8], Akram [13], and Flórez [6] among others).

We have also found that monetary policy variables account for substantial shares of fluctuations in oil, coal, and gold prices at all horizons.

In summary, we found two results that we would like to highlight. First, the response in prices to a shock in FFR is negative in all the cases and there is strong evidence of an overshooting as Frankel [5] suggests. Second, in average Colombian exported commodity price displays a stronger response to changes in US monetary policy.

\section{Disclosure}

The opinions expressed herein are those of the authors and do not necessarily reflect the views of Banco de la República or its Board of Directors.

\section{Conflict of Interests}

The authors declare that there is no conflict of interests regarding the publication of this paper.

\section{Acknowledgments}

The authors would like to thank Hernando Vargas, Carlos Huertas, Carmińa Vargas, and Julián Parra for their valuable comments and suggestions.

\section{References}

[1] P. Cashin, H. Liang, and C. J. Mcdermott, "How persistent are shocks to world commodity prices?" IMF Staff Papers, vol. 47, no. 2, pp. 177-217, 2000.

[2] E. Borensztein and C. Reinhart, "The macroeconomic determinants of commodity prices," IMF Working Papers 94/9, International Monetary Fund, Washington, DC, USA, 1994.

[3] J. A. Frankel, "Commodity prices and money: lessons from international finance," American Journal of Agricultural Economics, vol. 66, no. 5, pp. 560-566, 1985.

[4] R. Dornbusch, "Expectations and exchange rate dynamics," Journal of Political Economy, vol. 84, no. 6, pp. 1161-1176, 1976.

[5] J. A. Frankel, "The effect of monetary policy on real commodity prices," NBER Working Papers 12713, National Bureau of Economic Research, New York, NY, USA, 2006.

[6] L. A. Flórez, Monetary Policy and Commodity Prices: An Endogenous Analysis Using a SVAR Approach. Borradores de Economía, vol. 610, Banco de la República de Colombia, 2010.

[7] J. D. Hamilton, "Understanding crude oil prices," The Energy Journal, vol. 30, no. 2, pp. 179-206, 2009.
[8] A. Anzuini, M. J. Lombardi, and P. Pagano, "The impact of monetary policy shocks on commodity prices," Working Paper Series 1232, European Central Bank, Frankfurt, Germany, 2010.

[9] S. Kim, "Do monetary policy shocks matter in the G-7 countries? Using common identifying assumptions about monetary policy across countries," Journal of International Economics, vol. 48, no. 2, pp. 387-412, 1999.

[10] S. Kim, "Monetary policy, foreign exchange intervention, and the exchange rate in a unifying framework," Journal of International Economics, vol. 60, no. 2, pp. 355-386, 2003.

[11] J. A. Frankel, "Expectations and commodity price dynamics: the overshooting model," The American Agricultural Economics Association, vol. 68, no. 2, pp. 344-348, 1985.

[12] L. E. Arango, F. Arias, and L. A. Flórez, Trends, Fluctuations, and Determinants of Commodity Prices, Borradores de Economía 521, Banco de la República de Colombia, 2008.

[13] Q. F. Akram, "Commodity prices, interest rates and the dollar," Energy Economics, vol. 31, no. 6, pp. 838-851, 2009.

[14] F. Browne and D. Cronin, "Commodity prices, money and inflation," Journal of Economics and Business, vol. 62, no. 4, pp. 331-345, 2010.

[15] M. Lombardi, C. Osbat, and B. Schnatz, "Global commodity cycles and linkages a favar approach,” Working Paper Series 1170, European Central Bank, 2010.

[16] J. A. Frankel and A. K. Rose, "Determinants of agricultural and mineral commodity prices," in Inflation in an Era of Relative Price Shocks, R. Fry, C. Jones, and C. Kent, Eds., RBA Annual Conference Volume, Reserve Bank of Australia, 2010.

[17] M. D. Bordo, "The effects of monetary change on relative commodity prices and the role of long-term contracts," Journal of Political Economy, vol. 88, no. 6, pp. 1088-1109, 1980.

[18] P. Hall, The Bootstrap and Edgeworth Expansion, SpringerVerlag, New York, NY, USA, 1992. 

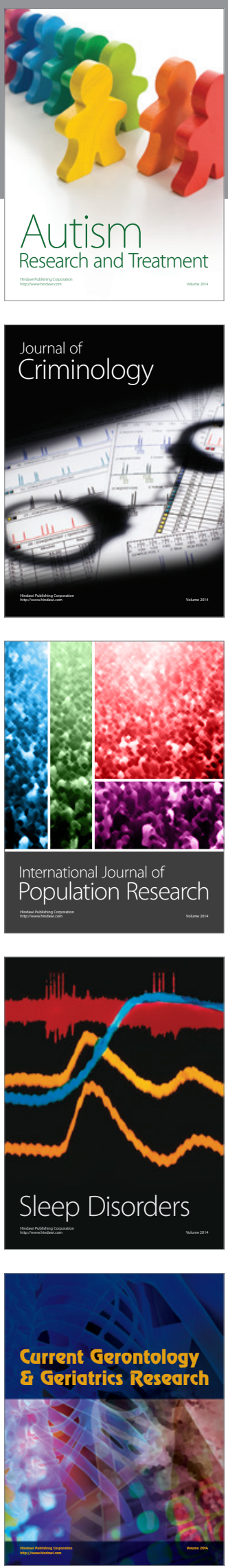
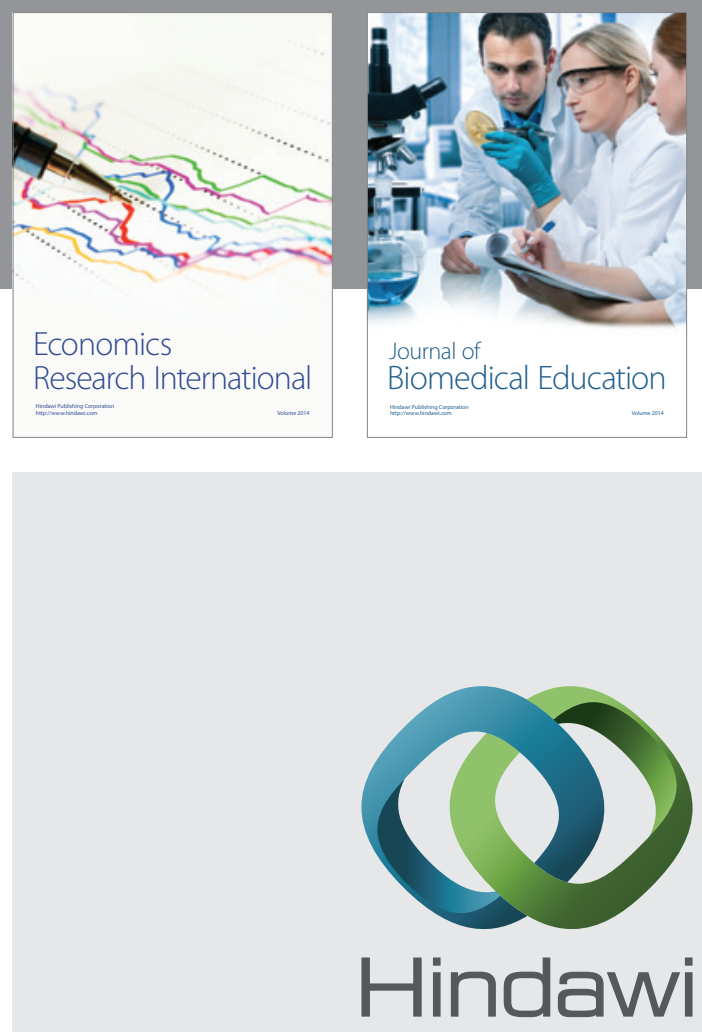

Submit your manuscripts at

http://www.hindawi.com
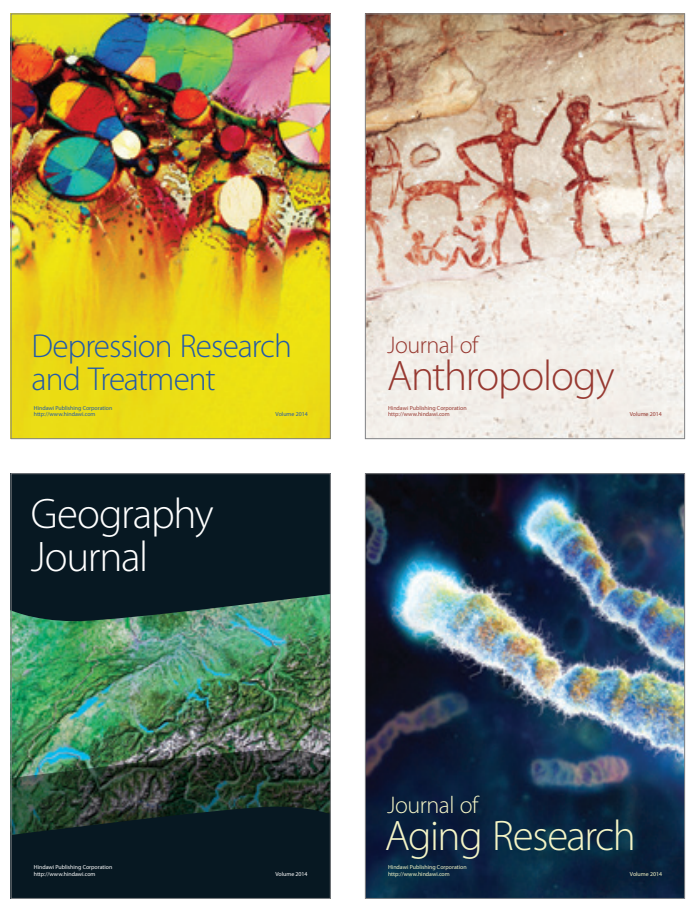
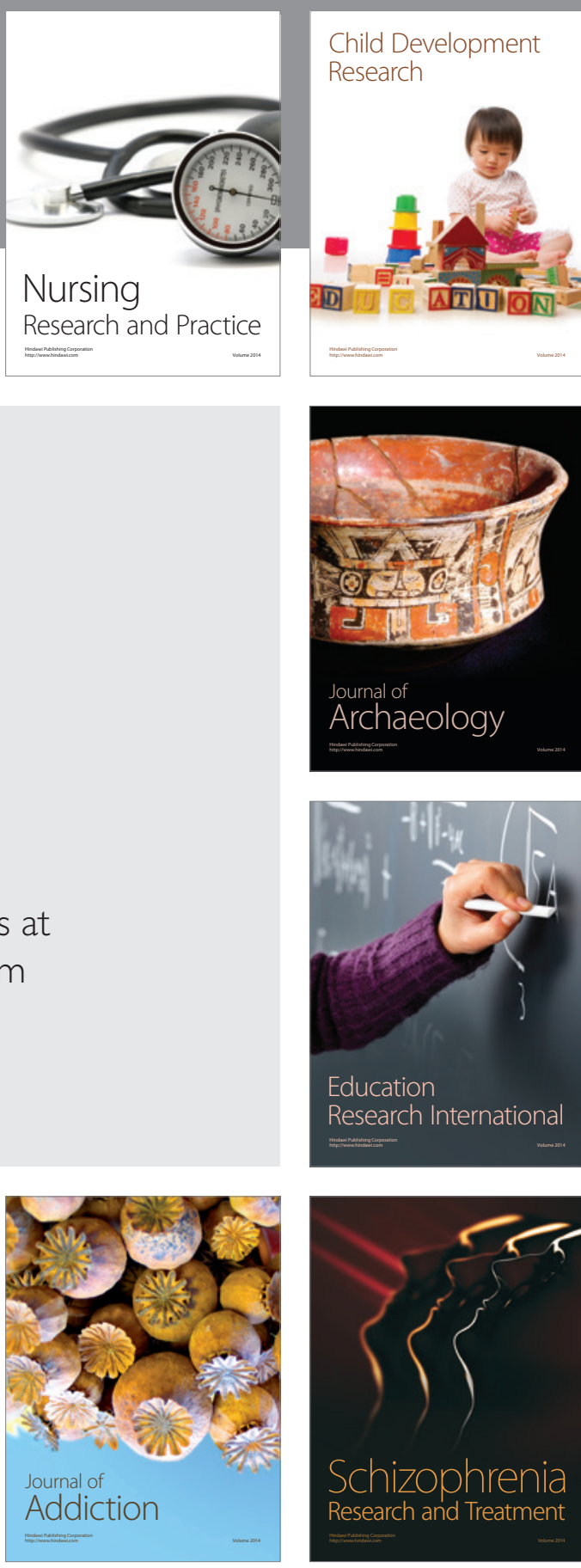

(D)
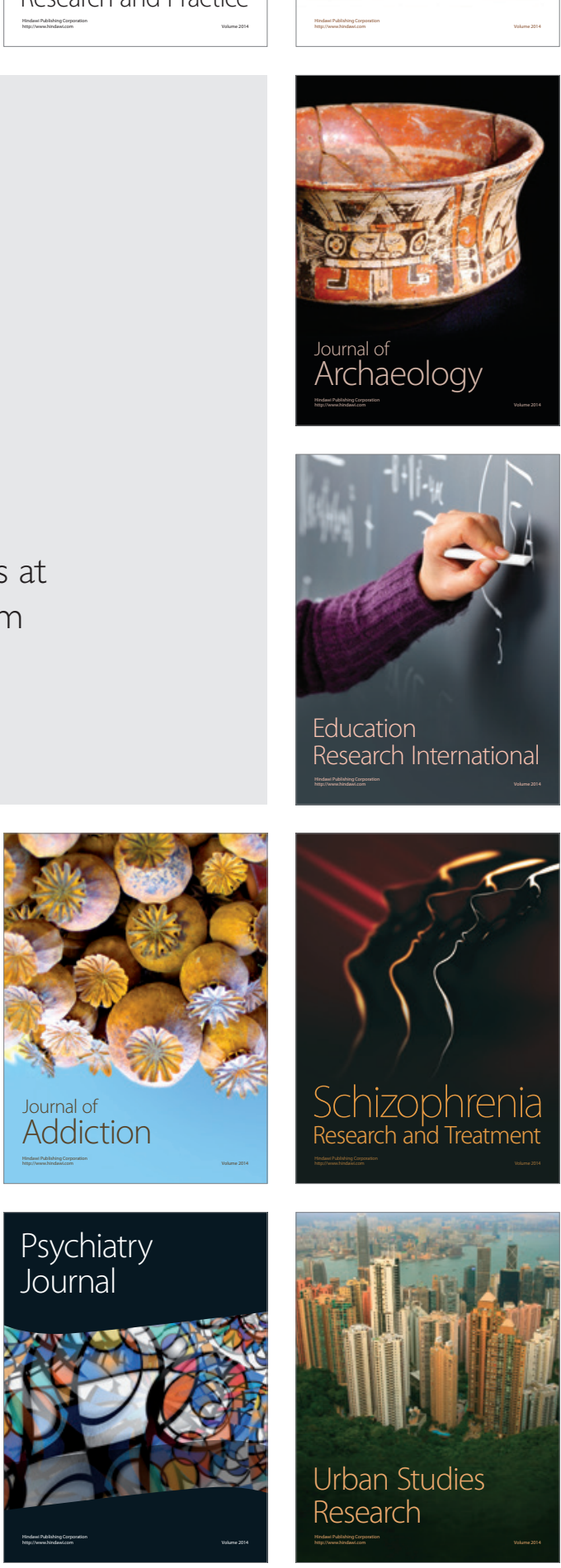